\title{
Construction of a high-rise unique residential building in the context of the old airport territory renovation in Rostov-on-Don
}

\author{
Svetlana Sheina, Yurii Maximenko, Aleksandr Danilenko, and Vladimir Belash* \\ Don State Technical University, 344010, Rostov-on-Don, Russia
}

\begin{abstract}
The article examines the specifics of the abandoned industrial areas renovation in modern conditions. The examples of such territories' renovation in the world and Russian practice and the methods of its implementation in the conditions of urban development on the old airport territory example in Rostov-on-Don are studied. The methodology for the territorial pre-investment assessment for the unique high-rise residential building construction has been developed. The option of constructing a unique high-rise residential building in the selected area is considered.
\end{abstract}

\section{Introduction}

Industrial enterprises were built mainly on the outskirts of the city in specially designated industrial zones on the territory of the Russian Federation. Over time, the population of the cities grew, the cities themselves grew simultaneously and the former outskirts of the city turned out to be far in the depths of the urban territory. At the end of the twentieth century, the socio-economic situation in our country changed dramatically, many enterprises went bankrupt and closed. As a result, a large number of industrial zones that are no longer functioning were revealed within the cities, this led to the fact that quite a lot of depressed spaces and neglected territories appeared in the urban environment, and the question of their renovation arose [1].

A good example of such spaces use is the European experience in the renovation of such industrial zones as Gasholders in Vienna (Fig. 1), Karlsruhe Center for Art and Media in (Fig. 2), Gelisen Kirchen Quarter in Germany.

\footnotetext{
*Corresponding author: rgsu-gsh@mail.ru
} 


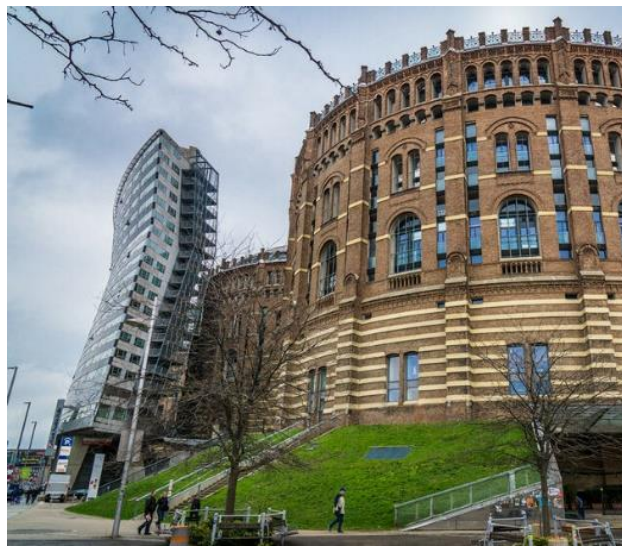

Fig. 1. Gasholders in Vienna.

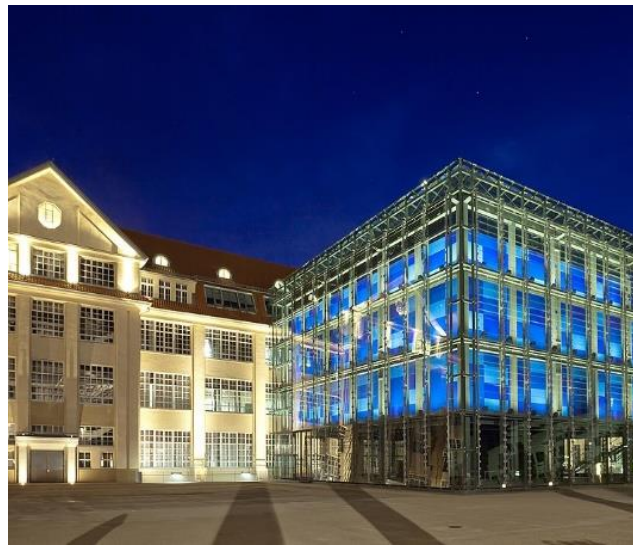

Fig. 2. Karlsruhe Center for Art and Media.

Studies have shown that renovation through complete demolition can exceed the planned costs, as prices for dismantling, land clearing and disposal of construction waste increase.

HafenCity in Hamburg is a prime example of the global experience in renovation. In the middle of the twentieth century, the port ceased to function, a new port was built for ships, the rest of the harbor was abandoned. In 1999, two architectural firms Hamburgplan and Kees Christiaanse / ASTOC became the winners of the competition for the area renovation. Based on the master plan: $30 \%$ of the land was allocated for housing, $50 \%$ for offices, the rest - for infrastructure and public spaces. To date, the construction has not yet been finally completed. It is there that the famous Elbe Philharmonic, designed by Herzog \& de Meuron Architekten, and the HafenCity University are located $[2,3]$.

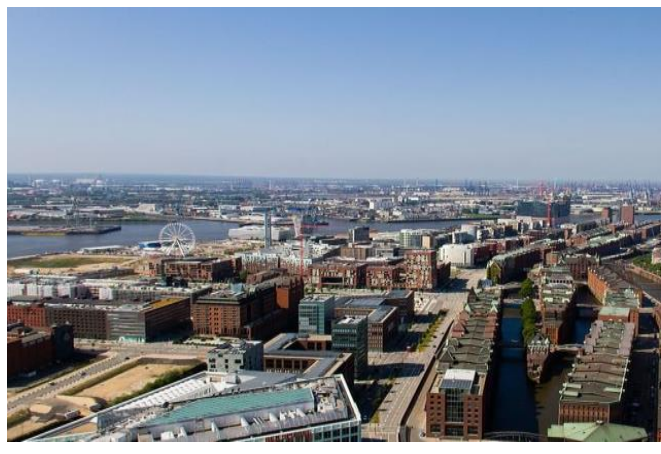

Fig. 3. HafenCity Renovation.

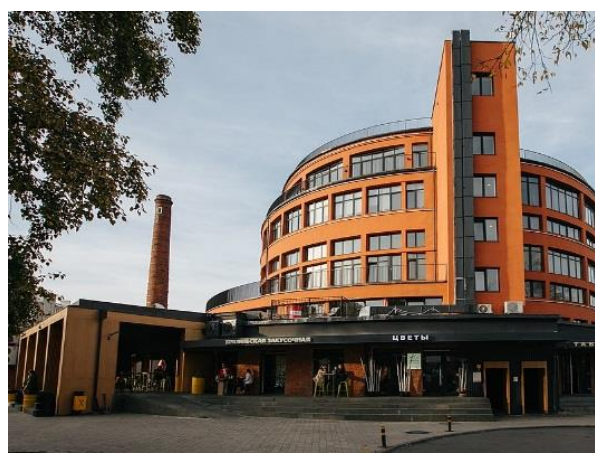

Fig. 4. Bakery No. 9 in Moscow.

On the territory of Russia, the examples of renovation can be called, in particular, Bakery No. 9 (Fig. 4) in Moscow. [4.5]. After the plant closure, it was not demolished, the factory premises were re-equipped and in just three years many different establishments were housed in them [5].

There are also a large number of industrial zones on the territory of Rostov-on-Don, in which renovation has been carried out. One of the latest projects underway to renovate the industrial zones of Rostov-on-Don is the Krasny Aksai residential complex (Fig. 5). Earlier on the territory of this residential complex there was a plant for the agricultural equipment manufacture. The renovation of the former factory site started in 2016, and by the end of 2021 the project will have been completed. It is planned to build 26 apartment buildings; the building area is about 25 hectares. 
It is also necessary to note the RC "Aquarelle" (Fig. 6.) in the area of the Tekuchevsky bridge. In 2015, the land plot of the former ball bearing plant No. 4 on Skachkova Street was a part of the renovation program. On the bank of the Temernik River, 5 apartment buildings with an area of 57 thousand square meters were built.

In 2021, it is planned to complete the construction of the Ekaterininsky residential complex on the western outskirts of the city (Fig. 7). The construction of this residential complex is taking place on the territory of the former Don-Gypsum plant. The total building area is about 190 thousand square meters.

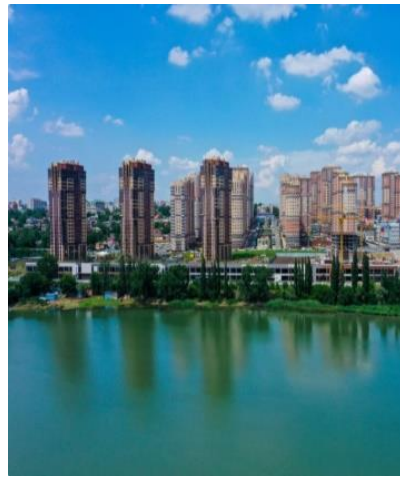

Fig. 5. Residential complex «Krasny Aksay».

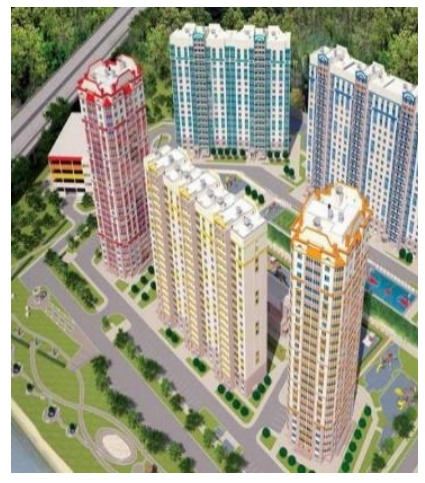

Fig. 6. Residential complex «Aquarelle».



Fig. 7. Residential complex «Ekaterininsky».

One of the most interesting projects is the old airport territory renovation in the city of Rostov-on-Don. After the modern airport complex "Platov" was put into operation at the end of 2017 to meet the needs of the Rostov Agglomeration, it became possible to build a new residential neighborhood on the territory of the old Rostov airport. The total area of the building site is 350 hectares, suitable for renovation (Fig. 8) [6].

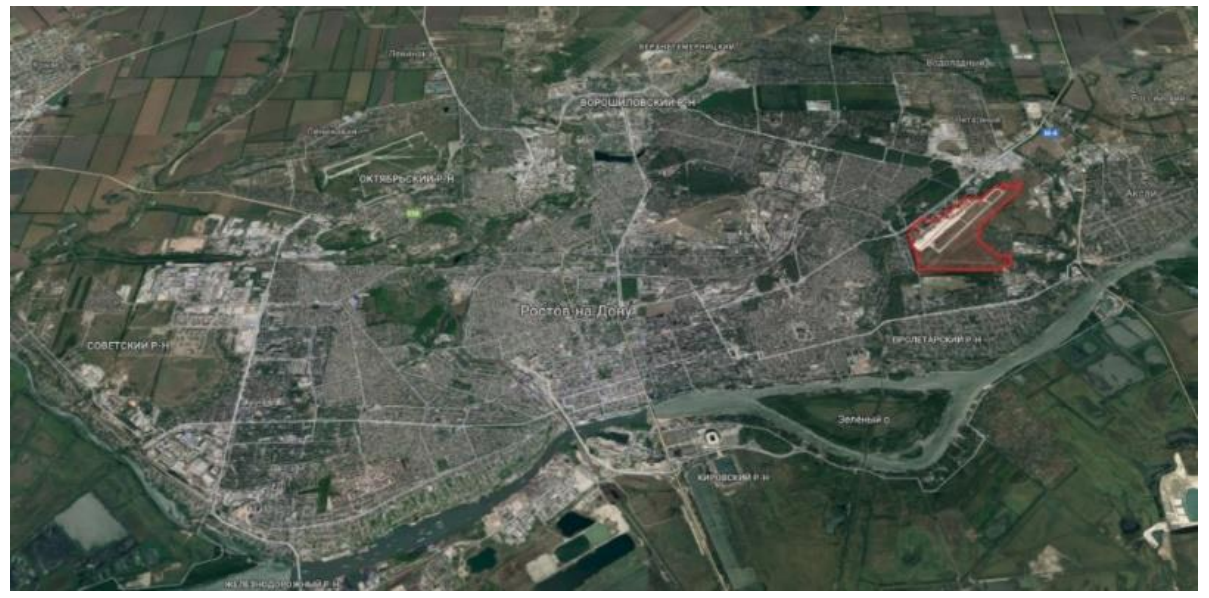

Fig.8. The territory of the old airport on the map of Rostov-on-Don.

Several options for design solutions were presented for consideration, among which a proposal developed by the architectural studio of the French architect Anthony Béchu deserves attention. According to the project, it was planned to build an area of low-rise and multi-storey buildings, the area of which is more than 2.5 million square meters of housing 
that meets all modern requirements. Laying of engineering communications networks and the construction of all necessary infrastructure was provided $[7,8]$.

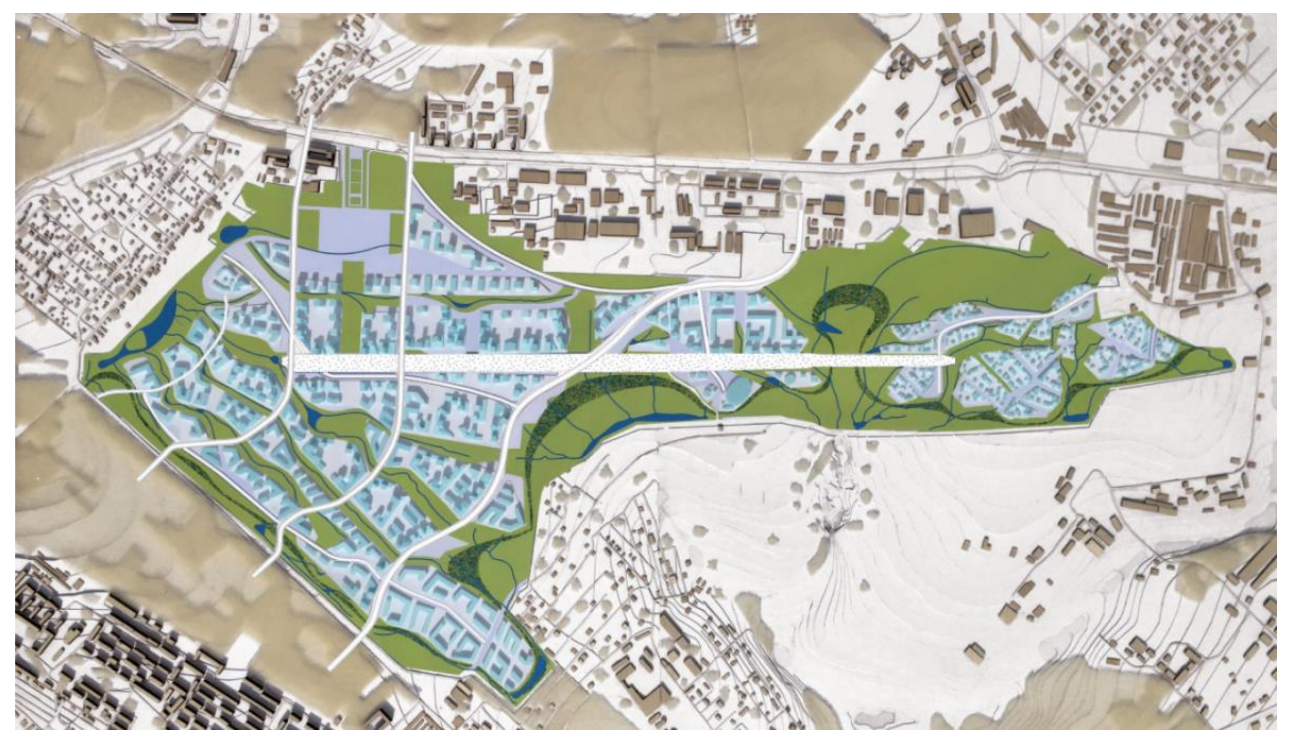

Fig. 9. Residential area "Aviator" on the territory of the old airport in Rostov-on-Don (arch. Beshu)

As a part of the renovation project, we will consider the problem of assessing the suitability of a given area for the purpose of high-rise unique construction.

\section{Materials and methods}

As a part of the research, a method for the pre-investment assessment of the territory for the construction of a unique high-rise residential building has been developed (Fig.10).

The technique consists of four stages:

Stage 1. Analysis of the regulatory framework.

Stage 2. Urban planning analysis of the territory, including its comprehensive assessment by seven indicators (Table 1)

Stage 3. Analysis of additional indicators, including the data on the need for resettlement, demolition, etc. (Table 2).

Stage 4. General conclusion about the suitability degree of the territory for the residential building construction [9]. 


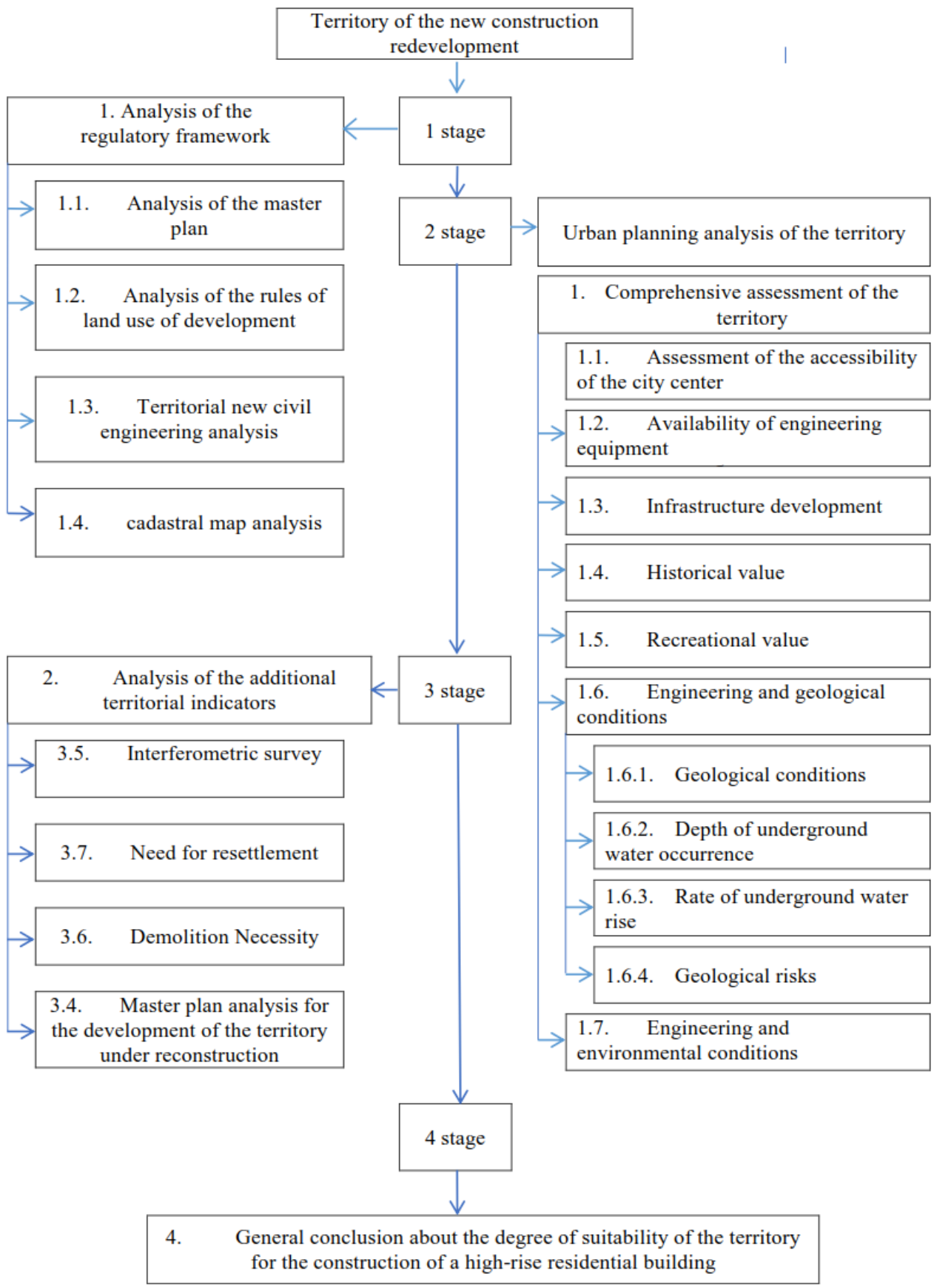

Fig. 10. Methodology of pre-investment assessment of the territory of renovation

\section{Research results}


The implementation of the methodology is presented on the example of a high-rise unique 34-storey residential building construction during the old airport territory renovation in Rostov-on-Don.

\section{Stage 1. Analysis of the regulatory framework}

1.1. Analysis of the master plan made it possible to assess the existing territory and estimate the volume of new housing construction. In the development area, there are residential areas, public and business areas and areas of service facilities necessary for the industrial and entrepreneurial activities implementation (Fig.11).

1.2. Analysis of the land use rules for the development made it possible to determine that the object will be located in the zone IO-2. Urban planning regulations for territorial zones of the IO-2 type are designed to ensure the legal conditions for the formation, development and maintenance of the territories intended for housing objects of housing construction, public services, recreation and facilities for creating environmentally friendly places of employment by repurposing predominantly production territories (Fig. 12).

1.3 After analyzing the map of the general plan of the new housing construction in the city, we can conclude that the territory of the old airport is promising for the urban development of residential and public and business buildings (Fig. 13).

1.4. In accordance with the cadastral map, the site of the old airport, under the number 0020202 , the area of the site is 2652401 sq. m., and the cadastral value is 4907313 rubles (Fig. 14) [10].

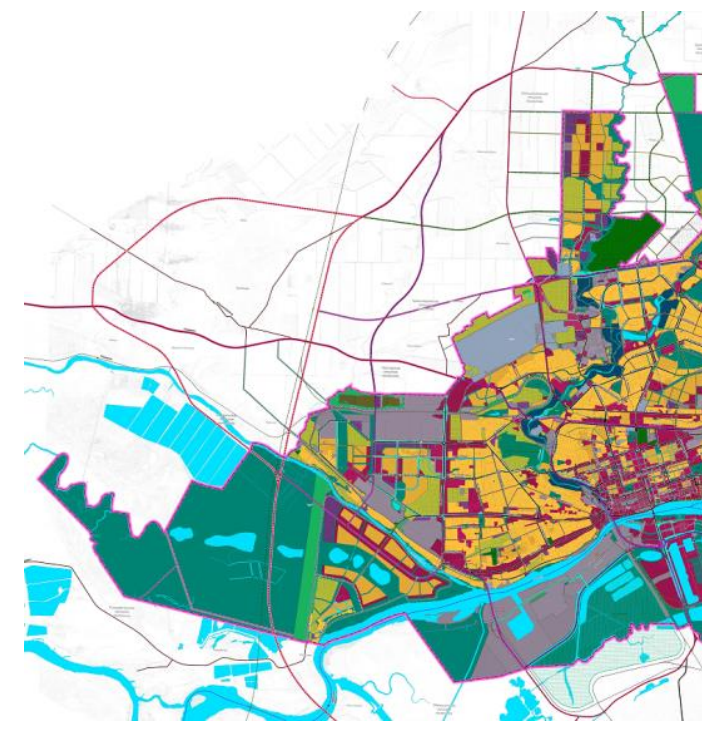

Fig. 11. General plan

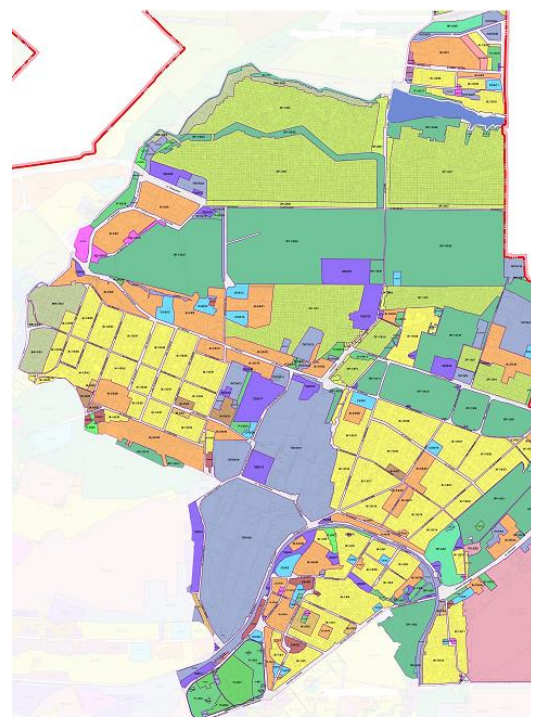

Fig. 12. Land use rules for development 


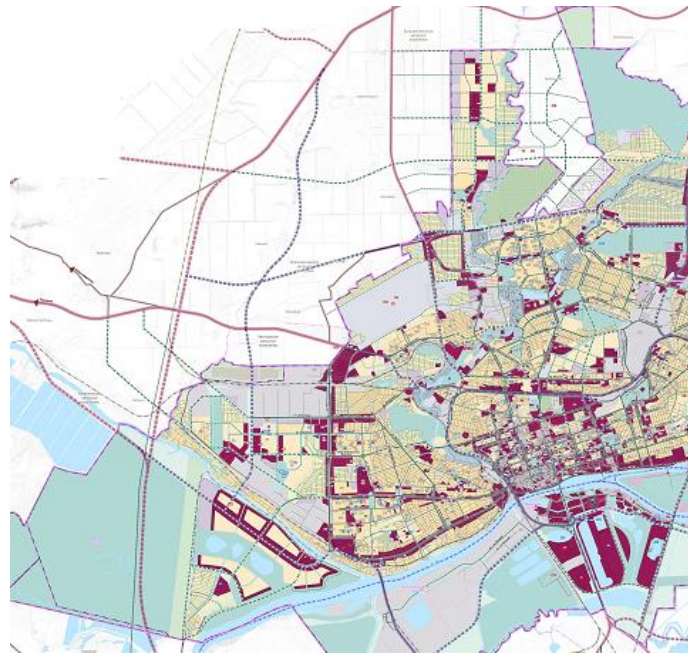

Fig. 13. Territories of new housing construction



Fig.14. Cadastral map

\section{Stage 2. Urban planning analysis of the territory. Comprehensive analysis of the territory}

To conduct a comprehensive assessment of the territory, the information base, made in the ARC GIS10.1 environment, which integrates electronic maps of the city of Rostov-on-Don was used, built according to the following factors:

1. Accessibility of a public and business, administrative center;

2. Engineering level (communications, transport);

3. The level of the cultural and consumer services sphere development for the population;

4. Presence of monuments of history and culture;

5. Environmental conditions;

6. Geotechnical conditions affecting construction;

7. Landscape and recreational conditions.

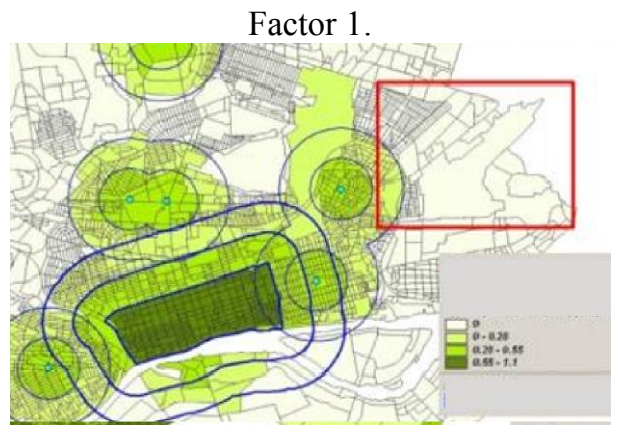

Fig. 15. Accessibility of the public-business, administrative center

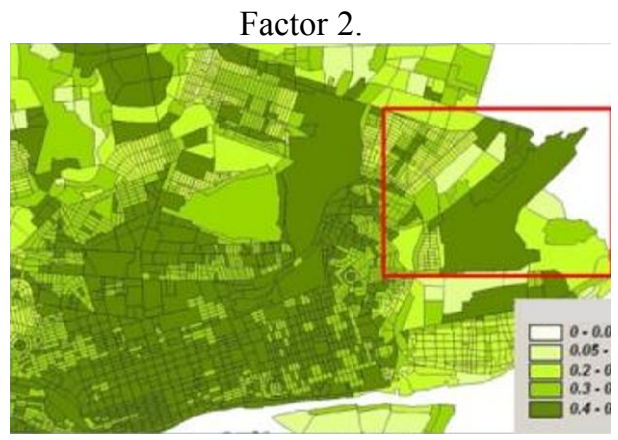

Fig. 16. Level of engineering arrangement (communications, transport)

Factor 3.

Factor 4. 


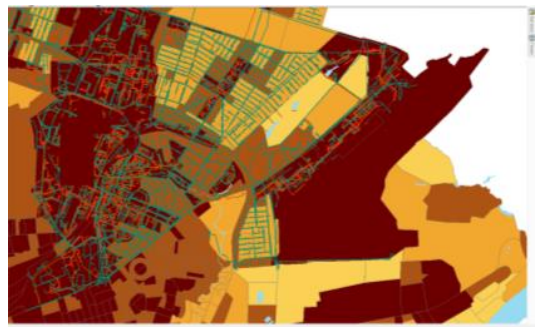

Fig. 17. The level of the cultural and consumer services sphere development for the population



Fig. 18. The presence of historical and cultural monuments

\section{Factor 5.}



Fig. 19. Environmental conditions
Factor 6.

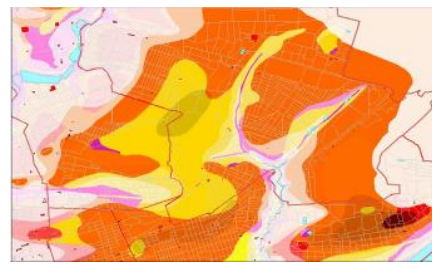

Fig. 20. Geological risk
Factor 7.

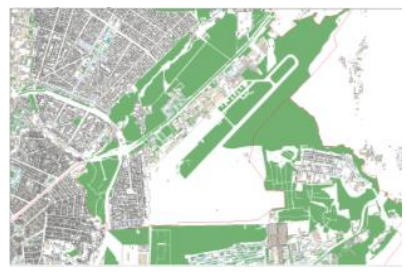

Fig. 21. Landscape and recreational conditions

Table 1. Factors of the relative value of the territory and their assessment

\begin{tabular}{|l|l|}
\hline \multicolumn{1}{|c|}{ Name of indicators } & \multicolumn{1}{c|}{ Relative value coefficient $\mathbf{K}$} \\
\hline $\begin{array}{l}\text { 1. Accessibility of the public-business, } \\
\text { administrative center. }\end{array}$ & $\mathrm{K}=0$, no availability available. \\
\hline $\begin{array}{l}\text { 2. Level of engineering arrangement } \\
\text { (communications, transport) }\end{array}$ & $\mathrm{K}=0.46$, average \\
\hline $\begin{array}{l}\text { 3. The level of development of the sphere of } \\
\text { cultural and consumer services of the population. }\end{array}$ & $\mathrm{K}=0.4$, average \\
\hline $\begin{array}{l}\text { 4. The presence of historical and cultural } \\
\text { monuments }\end{array}$ & $\mathrm{K}=0.40$ \\
\hline 5. State of the environment & Low-risk \\
\hline 6. Geological risk & $\mathrm{Geological} \mathrm{risk} \mathrm{zone-dangerous}$ \\
\hline 7. Landscape and recreational conditions & $\mathrm{K}=0$ \\
\hline
\end{tabular}

\section{Stage 3. Analysis of additional indicators}

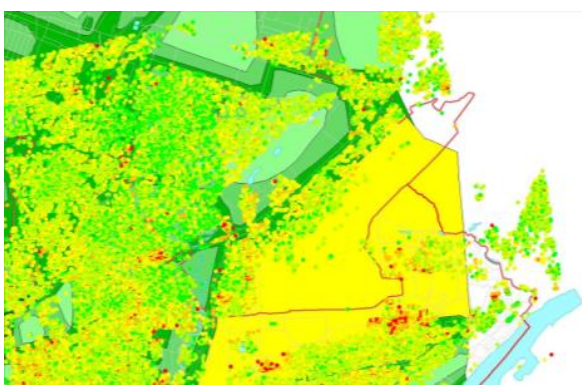

Fig. 22. Interferometric survey

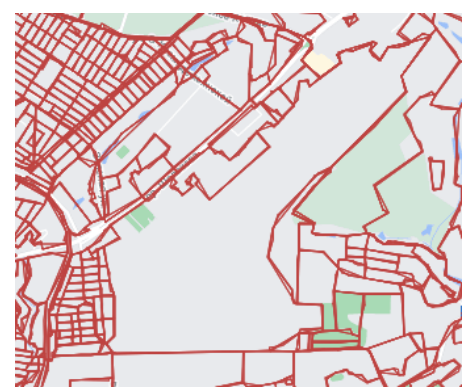

Fig.23. Cadastral map 
Table 2. Factors for evaluating additional indicators

\begin{tabular}{|l|l|}
\hline 1. Interferometric survey & $\begin{array}{l}\text { No significant deformation of the Earth's } \\
\text { surface is observed }\end{array}$ \\
\hline 2. The need for resettlement & Resettlement is not required in this area \\
\hline 3. Demolition necessity & $\begin{array}{l}\text { Demolition of industrial buildings is required } \\
\text { on the territory }\end{array}$ \\
\hline
\end{tabular}

\section{Stage 4. General conclusion about the suitability degree on the territory for the residential building construction}

From the analysis of the reconstruction territory, it can be concluded that the territory of the old airport of Rostov-on-Don is suitable for the construction of a unique, multi-storey residential building. [11]

A 34-storey unique high-rise residential building is expected in accordance with the presented master plan (Fig. 24), on the territory of XL scale.

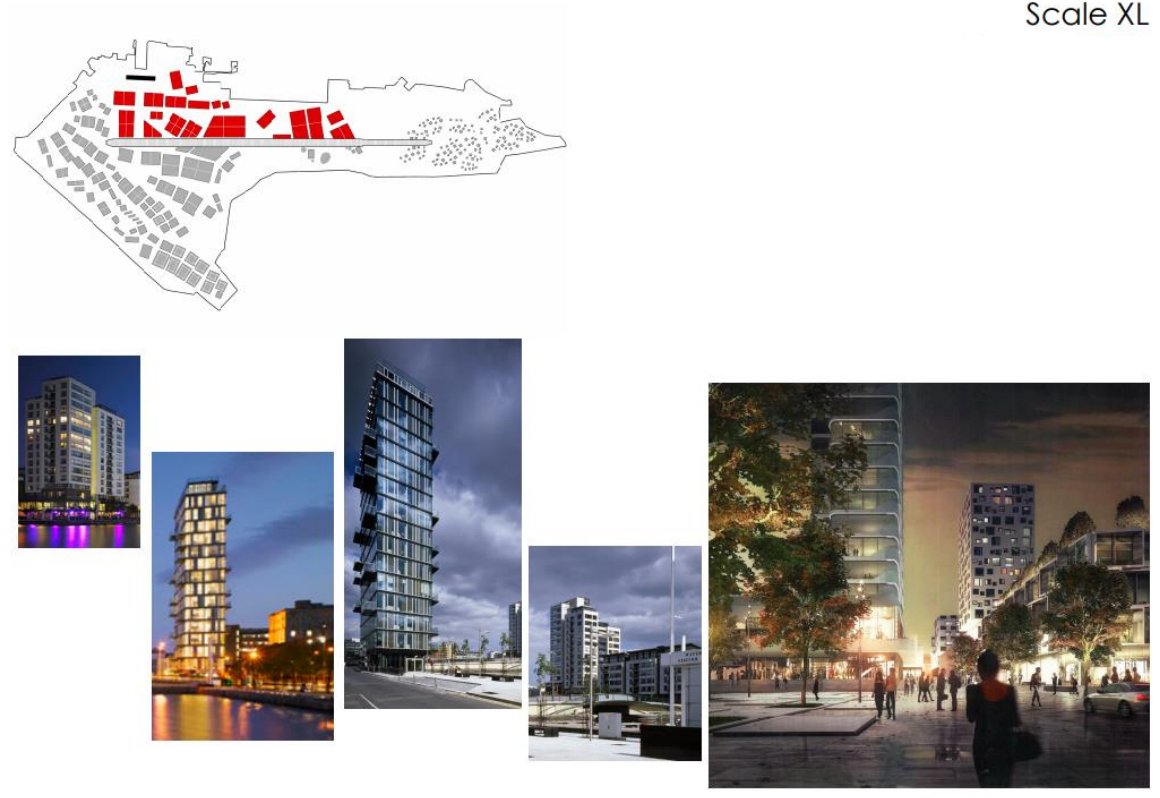

Fig. 24. XL-scale development area

\section{Architectural and planning solutions of a residential building}

An apartment building with non-residential premises on the ground floor and technical floors (18th and 34 th floors) is a detached one-section 34-storey building.

The residential building in the plan has a rectangular shape in the plan with the dimensions in the axes of $32.04 \times 19.7 \mathrm{~m}$. The total height of the building (up to the overlap of the 34th floor) is $102.2 \mathrm{~m}$, the height of the top point of the building is $109 \mathrm{~m}$. The centric principle laid down in the basis of the building composition, made it possible to obtain a planning solution that meets the natural and climatic conditions of Rostov-on-Don. Floors height is:

- basement 3,0 m;

- 1 floor $3,3 \mathrm{~m}$; 
- 2-34 (residential floors);

- technical floor 1.75 (from floor to bottom of floor slabs).

The nomenclature of designed apartments is as follows:

- 2-room 160 apt;

- 3-room 64 apt.

The house has 2 fire-prevention ladders and 4 elevators with a lifting capacity of $1000 \mathrm{~kg}$.

The "Smart Home" technology is proposed [12,13].

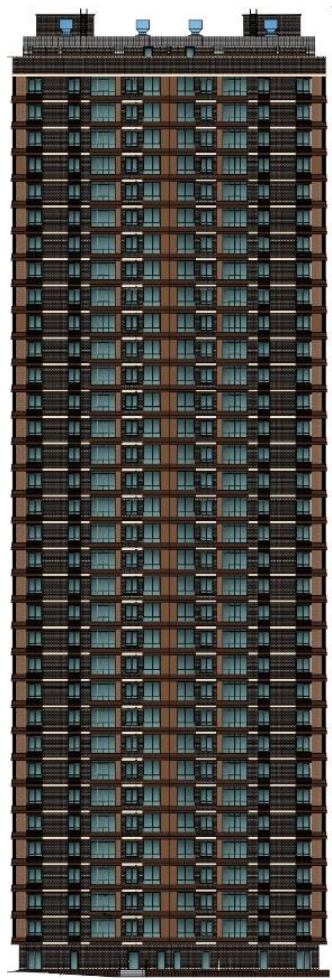

Fig.25. 34-storey high-rise building

\section{Conclusions}

The analysis of the world and Russian experience in the renovation of abandoned industrial areas showed the need and the possibility of renovating the territory of the old airport in the city of Rostov-on-Don. A methodology for the pre-investment assessment of the territory for the construction of a high-rise unique residential building including a comprehensive assessment of the territory according to a number of priority indicators, has been developed.

The results of a comprehensive assessment of the old airport territory in the city of Rostov-on-Don showed that the latter is suitable for the construction of a new micro-district "Aviator", where the construction of a unique high-rise residential building is planned. A project for the construction of a 34-storey residential building has been developed, taking into account modern requirements and the "Smart Home" technology. 


\section{References}

1. E. V. Demidova, Academic Bulletin Ural Scientific Project RAASN 1, (2013).

2. S. Foroughi, M.A. Rasol, The Egyptian Journal of Remote Sensing and Space Sciences 19, 323-332 (2016)

3. Yu.P. Balabanova, N.M. Budkevich, Bulletin of the Kazan State Architectural and Construction University (2018).

4. S. Ferrari, F. Zagarella, Energy Procedia 78, 2378 - 2384 (2015)

5. E.V. Nezhnikova, Economics and management of real estate 4, 20-24 (2016)

6. E.K. Sotnikova, S.G. Sheina, K.V. Chubarova, Engineering Bulletin of the Don 3, (2020).

7. A.V. Popov, Academic Bulletin Ural Scientific Project RAASN 1, 25-28 (2013)

8. M.A. Zolotykh, Electronic scientific student journal 2(6), (2017) URL: saf.petrsu.ru/journal/article.php?id=1183

9. S.G. Sheina, R.B. Matveyko, Bulletin of higher educational institutions. North Caucasian region. Technical science 4.10, (2010)

10. S.G. Sheina, A.A. Sukhinin, E.R. Shevtsyova, Construction and technogenic safety, (2018).

11. Yu.V. Popova, Construction and technogenic safety 13 (65), 29-33 (2018)

12. M.A. Girya, Engineering Bulletin of the Don 3 (50), 113 (2018).

13. S.G. Sheina, A.A. Fedorovskaya, R.V. Yudina, BCE: Bulletin of construction equipment 10(1010), 20-23 (2018). 